\title{
THE ROLE OF BATTERED INTERVENTION PROGRAMS IN FORMATION THE ATTITUDES AND BELIEFS OF THE CONVICTED PERPETRATORS OF DOMESTIC VIOLENCE
}

\section{ROLA PROGRAMÓW EDUKACYJNO-KOREKCYJNYCH W KSZTAETOWANIU POSTAW I PRZEKONAŃ SKAZANYCH SPRAWCÓW PRZEMOCY DOMOWEJ}

\begin{abstract}
The battered intervention programs are an important part of the system of preventing domestic violence. The main purpose of them is that the violence should stop and eliminate. These programs are related to correcting defective attitudes and beliefs of perpetrators that support or excuse violence towards family members. Many studies have shown relatively low effectiveness of these programs however, they have not provided clear evidence of their ineffectiveness. The aim of this article is an attempt to answer the question: Do such programs actually shape the attitudes and beliefs of perpetrators of domestic violence? The author has analysed the data of the survey which was carried out in nine prisons in the Podkarpackie Voivodship. The sample consisted of 277 convicted perpetrators of domestic violence. They were made up of 133 men who have completed the batterer intervention programs (experimental group) and 144 men who have never participated in them (control group). Studies have shown there were no statistically significant differences between the two groups of perpetrators. Their attitudes and beliefs about their own violent behaviours in family were relatively similar.
\end{abstract}

\section{STRESZCZENIE}

Programy edukacyjno-korekcyjne dla sprawców przemocy domowej stanowią istotną część systemu przeciwdziałania przemocy w rodzinie. Ich zasadniczym celem jest powstrzymanie sprawców przed krzywdzeniem członków rodziny i zatrzyma- 
nie przemocy. Są one ukierunkowane na korygowanie niepożądanych i wadliwych postaw oraz przekonań sprawców, które pozwalają im „usprawiedliwiać” stosowaną w rodzinie przemoc. Dotychczasowe badania dowodzą stosunkowo niskiej efektywności tych programów, choć brak też jednoznacznych dowodów, iż są one całkowicie nieskuteczne. Celem niniejszego artykułu jest próba odpowiedzi na pytanie, czy i jakie znaczenie mają programy edukacyjno-korekcyjne w kształtowaniu postaw i przekonań sprawców przemocy domowej. Analizie poddano dane pochodzące $\mathrm{z}$ badań ankietowych zrealizowanych $\mathrm{w}$ dziewięciu zakładach karnych na terenie województwa podkarpackiego. Przebadano 277 mężczyzn skazanych za znęcanie się nad członkiem rodziny, w tym 133 sprawców, którzy ukończyli programy edukacyjno-korekcyjne (grupa eksperymentalna) i 144 skazanych, którzy nie brali udziału w tego rodzaju oddziaływaniach (grupa kontrolna). Analiza wyników dowiodła bra$\mathrm{ku}$ istotnych statystycznie różnic pomiędzy badanymi, jeśli chodzi o przyjmowane przez nich postawy wobec własnych zachowań związanych ze stosowaniem przemocy $w$ rodzinie.

KEYWORDS: domestic violence, perpetrators of domestic violence, batterer intervention programs, effectiveness, formation of attitudes and beliefs, process of change

SŁOWA KLUCZOWE: przemoc domowa, sprawcy przemocy, programy edukacyjno-korekcyjne, efektywność, ksztattowanie postaw i przekonań, proces zmian

\section{WPROWADZENIE}

Przemoc $\mathrm{w}$ rodzinie traktowana jest $\mathrm{w}$ naszym kraju jako szczególny problem społeczny, który domaga się określonej polityki społecznej i kryminalnej. Każdego roku Policja ujawnia ok. 75 tys. przypadków przemocy w rodzinie, w których odnotowuje się ponad 90 tys. osób pokrzywdzonych. Najczęściej ofiarami przemocy domowej stają się kobiety, które stanowią ponad 70\% ogółu osób poszkodowanych, zaś przemocy domowej najczęściej dopuszczają się mężczyźni, będąc sprawcami w ponad 90\% ujawnionych przypadków przemocy (obliczenia procentowe własne, na podst. http://statystyka.policja.pl). Także ogólnopolskie badania sondażowe pokazują dużą skalę tego zjawiska, dowodząc, że problemem przemocy domowej może być dotknięta nawet co piąta rodzina. Przykładowo, badania zrealizowane przez TNS OBOP na zlecenie Ministerstwa Pracy i Polityki Społecznej wykazały, że ok. 22\% dorosłych Polaków, przynajmniej raz w życiu doznało przemocy ze 
strony członka rodziny, przy tym wyraźnie częściej były to kobiety (26\%) niż mężczyźni (16\%) (TNS OBOP, 2010, s. 48). Ze względu na wagę problemu przemocy domowej, od kilkunastu lat w Polsce poszukuje się skutecznych sposobów przeciwdziałania temu zjawisku. Aktualny system przeciwdziałania przemocy w rodzinie, który oparto na rozwiązaniach zapisanych w ustawie z 2005 r. i kolejnych przepisach nowelizujących, przewiduje szereg zadań realizowanych przez organa administracji rządowej, jednostki samorządu terytorialnego oraz organizacje społeczne, wśród których wyodrębniono nie tylko procedury udzielania pomocy osobom pokrzywdzonym (m.in. pomoc medyczna, prawna, psychologiczna, socjalna, udzielenie bezpiecznego schronienia i wiele innych), ale także szereg oddziaływań wobec osób dopuszczających się znęcania nad osobami bliskimi (m.in. oddziaływanie interwencyjne, prawnokarne, lecznicze i terapeutyczne).

W postępowaniu ze sprawcami przemocy domowej istotną część polskiego systemu przeciwdziałania przemocy $\mathrm{w}$ rodzinie stanowią programy edukacyjno-korekcyjne. Ich zasadniczym celem jest, jak nadmieniono w $W y$ tycznych do tworzenia modelowych programów korekcyjno-edukacyjnych dla osób stosujących przemoc $w$ rodzinie, powstrzymanie sprawców przed dalszym krzywdzeniem członków rodziny, zatrzymanie i wyeliminowanie przemocy (zob. załącznik 2, cz. I, pkt 1). Udział osób dopuszczających się przemocy w tego rodzaju programach ma na celu zdobycie i poszerzenie przez nich wiedzy na temat mechanizmów powstawania przemocy, rozwijanie umiejętności samokontroli i współżycia w rodzinie oraz umiejętności komunikowania się i rozwiązywania konfliktów, bez krzywdzenia osób najbliższych, a także kształtowanie ich postaw odpowiedzialności za przemoc, bez obwiniania członków rodziny, a zwłaszcza ofiar przemocy (szerzej, zob. $₫ 4$ pkt 1-7 Rozporządzenia Ministra Pracy i Polityki Społecznej z dnia 22 lutego 2011 r.). Istotą tego rodzaju programów jest więc m.in. korygowanie, poprzez odpowiednio ukierunkowaną edukację, niepożądanych i szkodliwych postaw i przekonań sprawców przemocy domowej, szczególnie tych, które legitymizują czy „usprawiedliwiają” stosowanie przez nich przemocy (Głowik, 2013, s. 16; Witkowska-Paleń, 2017, s. 179).

Kierowanie osób dopuszczających się przemocy domowej do uczestnictwa w programach edukacyjno-korekcyjnych przewiduje Ustawa z dnia 29 lipca 
2005 r. o przeciwdziałaniu przemocy w rodzinie (zob. art. 4 u.p.p.r.). Tego rodzaju oddziaływaniami zazwyczaj obejmowane są osoby zobowiązane do uczestnictwa w programach na podstawie wyroku sądowego za przestępstwo „znęcania się" nad osobą bliską (art. 207 k.k.), i są to zarówno osoby odbywające karę pozbawienia wolności, jak też skazani poddani próbie w środowisku otwartym (np. resocjalizacji w warunkach dozoru kuratorskiego). Do programów edukacyjno-korekcyjnych kierowane mogą być również osoby dopuszczające się przemocy w rodzinie, które poddane zostały terapii uzależnień (wówczas udział w programie stanowi dla nich uzupełnienie podstawowej, a więc odwykowej terapii). Ponadto, oddziaływaniom o charakterze edukacyjno-korekcyjnym mogą poddać dobrowolnie i z własnej inicjatywy wszystkie inne osoby stosujące przemoc w rodzinie (zob. $\$ 5$ pkt 1-3 Rozporządzenia Ministra Pracy i Polityki Społecznej z dnia 22 lutego 2011 r.).

Ogólnie, jak dowodzą dane statystyczne, najliczniejszą grupę uczestników programów edukacyjno-korekcyjnych w Polsce (ok. ${ }^{2} /{ }_{3}$ ogółu) stanowią skazani przebywający w izolacji penitencjarnej (Ministerstwo Pracy i Polityki Społecznej, 2015, s. 132). Ponadto, w literaturze przedmiotu podkreśla się, że wielu sprawców przemocy, którzy ukończyli program w zakładzie karnym, dobrowolnie nie skorzystałoby z takiej oferty w środowisku otwartym (Lizińczyk, 2012a, s. 10).

Oferta programowa dla sprawców przemocy domowej w zakładach karnych, podobnie jak i w środowisku otwartym, najczęściej obejmuje program pod nazwą The Duluth Model (którego złożenia opracowano w latach 70. XX w. w Bostonie) i powstały na jego bazie program Partner. W niektórych jednostkach penitencjarnych realizowane są także różne autorskie programy oddziaływań względem skazanych (Lizińczyk, 2012b, s. 8; Wojciechowski i Sankowski, 2017, s. 148; Łuka, 2010, s. 80).

\section{CZY PROGRAMY EDUKACYJNO-KOREKCYJNE SĄ SKUTECZNE?}

W środowisku zarówno badaczy, jak i praktyków od dawna trwa dyskusja nad efektywnością programów dla sprawców przemocy domowej. Od wielu lat prowadzone są również badania w tym zakresie, zwłaszcza w krajach anglosaskich, które skądinąd cieszą się stosunkowo długą tra- 
dycją $\mathrm{w}$ realizacji tego rodzaju oddziaływań wobec sprawców przemocy domowej. Jednak, jak dotychczas, badania te nie przyniosły jednoznacznych rezultatów, które umożliwiałyby ostateczne rozstrzygniecie kwestii, na ile oddziaływania te są skuteczne w powstrzymywaniu przemocy domowej. Ponadto, przyjmowane przez różnych badaczy odmienne kryteria „mierzenia” efektywności programów edukacyjno-korekcyjnych, znacząco utrudniają porównywanie ich wyników (szerzej, zob. Barnish, 2004, s. 89). Daniel G. Saunders i Richard M. Hamill, przygotowując raport na zlecenie Departamentu Sprawiedliwości Stanów Zjednoczonych, analizie poddali ponad 30 projektów badawczych w tym zakresie. Stwierdzili oni, iż w badaniach, w których podstawą oceny efektywności programu były wywiady z partnerkami sprawców przemocy domowej, wskaźnik „nawrotu” przemocy, w ciągu jednego roku po zakończeniu przez sprawcę programu, wahał się od ok. $1 /{ }_{3}$ do nawet $2 / 5$ badanych przypadków. Natomiast w badaniach, w których efektywność programu mierzono na podstawie policyjnych rejestrów - wskaźniki te były stosunkowo niskie i dotyczyły jedynie ok. 10-20\% przypadków (Saunders i Hamill, 2003).

Metaanalizy wyników badań oceniających skuteczność leczenia sprawców przemocy domowej dokonali również Julia C. Babcock, Charles E. Green i Chet Robie. Autorzy wybrali do analizy 22 projekty uznane za najbardziej rygorystyczne metodologicznie, gdyż uwzględniające, obok grup eksperymentalnych (uczestnicy programów edukacyjno-korekcyjnych), także grupy kontrolne (mężczyźni stosujący przemoc, niebędący uczestnikami takich programów). Przeprowadzona analiza wykazała, że średnio ok. 40\% mężczyzn, którzy uczestniczyli w programach edukacyjno-korekcyjnych, nie dopuszczało się kolejnych aktów przemocy domowej po zakończeniu programu, podczas gdy w grupie mężczyzn, którzy nie brali udziału w tego rodzaju oddziaływaniach - odsetek ten był tylko nieznacznie niższy i wynosił ok. 35\%. W związku z tym - jak podkreślali autorzy opracowania - istnieje jedynie 5-procentowy wskaźnik skuteczności programów dla sprawców przemocy domowej. Ale, jak podkreślali, po "przełożeniu” go na dane liczbowe, w samych tylko Stanach Zjednoczony ok. 42 tys. kobiet rocznie ma szanse „uniknąć” przemocy domowej (Babcock, Green i Robie, 2004, s. 1044-1045). 
W Polsce, programy edukacyjno-korekcyjne mają stosunkowo krótką tradycję i nie doczekały się jeszcze szeroko zaplanowanych badań, zwłaszcza tych o charakterze longitudinalnym.

Jedyne jak dotychczas badania ewaluacyjne, dotyczące programów realizowanych w zakładach karnych, przeprowadził w 2014 r. Instytut Wymiaru Sprawiedliwości. Badaniami objęto skazanych za przestępstwo znęcania się nad osobą bliską (art. 207 k.k.), zaś udział w nich wzięło 120 uczestników programów dla sprawców przemocy domowej (grupa eksperymentalna) i 80 skazanych, którzy nie zostali poddani takim oddziaływaniom (grupa kontrolna).

Przeprowadzone badania pozwoliły na wyodrębnienie trzech grup uczestników programów edukacyjno-korekcyjnych w zakładach karnych.

Grupę „najsłabszą” (13\% ogółu) stanowili skazani, którzy wykazywali niewielką aktywność w ramach programu, cechował ich brak poczucia odpowiedzialności za stosowaną w rodzinie przemoc oraz tendencja do umniejszania znaczenia swojego zachowania i obarczania winą za przemoc swoich ofiar. U tej grupy badanych, po zakończeniu programu, stwierdzono jedynie minimalne zmiany w sferze poznawczej (lub ich całkowity brak), a co za tym idzie - brak jakichkolwiek zmian w sferze emocjonalnej. Ta grupa badanych, jak podkreślali autorzy raportu, nie rokuje zmiany zachowania po opuszczeniu zakładu karnego.

W grupie „średniej” uczestników programów (była to najliczniejsza grupa uczestników, ok. 60\%) również zaobserwowano stosunkowo mało aktywny udział skazanych podczas zajęć o charakterze edukacyjno-korekcyjnym, jednak większość z nich przystosowała się do formalnych wymogów programu, mimo iż uczestniczyli w zajęciach motywowani przede wszystkim pragnieniem uzyskania indywidualnych korzyści (np. warunkowego przedterminowego zwolnienia). Ostatecznie jednak ok. $1 / 3 \mathrm{z}$ nich uznała własną odpowiedzialność za stosowaną w rodzinie przemoc i zrozumiała, że ich zachowania były krzywdzące dla członków rodziny, stąd też - jak podkreślali autorzy raportu - można przypuszczać iż „będą się oni starać brać odpowiedzialność za swoje zachowanie i stosować techniki zatrzymania przemocy".

Natomiast „najlepszą” grupę uczestników oddziaływań edukacyjno-korekcyjnych (27\% ogółu) cechowało, w odróżnieniu od pozostałych - duże zaangażowanie w programie, uznanie własnej odpowiedzialności za akty 
przemocy w rodzinie, a także przyswojenie technik powstrzymywania takich zachowań oraz pragnienie zmiany własnego postępowania. Jednakże i w tej grupie uczestników (u ok. połowy) zidentyfikowano pewne negatywne czynniki, które mogą sprzyjać dalszym zachowaniom przemocowym w rodzinie. I były to głównie: skłonność sprawców do nadużywania alkoholu (która bardzo często współwystępuje z problemem przemocy domowej), nieumiejętność rozpoznawania sygnałów złości czy zbyt idealny obraz siebie (Wójcik, Drapała i Więcek-Durańska, 2015, s. 239-241).

Ogólnie, różne badania dowodzą stosunkowo niskiej efektywności programów edukacyjno-korekcyjnych dla sprawców przemocy domowej. Jednak, jak podkreślają zachodni badacze, wciąż nie ma jednoznacznych dowodów, by twierdzić, iż programy te nie działają i nie mogą przyczynić się do ograniczenia liczby przypadków przemocy domowej (Jackson, Feder et. al., 2003, s. 27). Jednocześnie jednak niezbędna wydaje się weryfikacja niektórych założeń programowych oraz identyfikacja tych czynników i elementów programu, które ułatwiają proces zmian wśród ich uczestników. To zaś przyczynić się może do wypracowania skuteczniejszych programów interwencyjnych (Silvergleid i Mankowski, 2006, s. 139).

\section{ZAŁOŻENIA METODOLOGICZNE BADAŃ WŁASNYCH}

Dyskusja wokół efektywności programów edukacyjno-korekcyjnych skłoniła mnie do głębszego zainteresowania się tą problematyką. Zaprezentowane poniżej wyniki badań mają jedynie charakter cząstkowy, a celem niniejszego artykułu jest próba odpowiedzi na pytanie, czy udział sprawcy przemocy domowej w programie o charakterze edukacyjno-korekcyjnym wpływa na zmianę jego postaw i przekonań związanych ze stosowaną w rodzinie przemocą? Aby rozwiązać tak założony problem badawczy, należy dodatkowo wyodrębnić następujące pytania szczegółowe:

- czy osoby, które ukończyły programy edukacyjno-korekcyjne, przekonane są o skuteczności tego rodzaju oddziaływań w powstrzymywaniu przemocy domowej?

- czy przejawiają gotowość do zaprzestania krzywdzenia osób bliskich?

- czy skłonni są uznać własne zachowania związane z przemocą za krzywdzące dla członków rodziny? 
- a także, czy czują się odpowiedzialni za akty przemocy domowej, których dopuścili się w swoich rodzinach?

Przedmiotem analizy będą dane pochodzące $\mathrm{z}$ badań zrealizowanych w 2016 r. wśród mężczyzn skazanych za przestępstwo znęcania się nad osobą bliską (art. 207 k.k.). Badania prowadzone były w dziewięciu jednostkach penitencjarnych podległych Okręgowemu Inspektoratowi Służby Więziennej w Rzeszowie, tj. w zakładach karnych w Chmielowie, Dębicy, Jaśle, Sanoku, Łupkowie, Medyce, Przemyślu, Rzeszowie i Uhercach Mineralnych. Włącznie przebadano 277 skazanych. Badania miały charakter anonimowy i realizowane były $\mathrm{z}$ zastosowaniem specjalnie przygotowanego kwestionariusza ankiety $\mathrm{z}$ wystandaryzowanym zestawem pytań.

W badanej próbie najliczniejszą grupę stanowili mężczyźni żyjący $\mathrm{w}$ intymnych związkach - tj. małżeńskich (ok. 35\%) lub konkubenckich (ok. 14\%). Mężczyźni ci dopuszczali się przemocy głównie wobec swoich partnerek życiowych (niektórzy także wobec własnych dzieci). Średnio co czwarty badany był po rozwodzie lub pozostawał w separacji małżeńskiej (ok. 27\%), zaś ofiarami aktów stosowanej przez nich przemocy były przede wszystkim ich eks-partnerki. Natomiast niespełna co czwarty mężczyzna był kawalerem i nie posiadał stałej partnerki (ok. 24\%), a przemocy dopuszczał się wobec swoich rodziców (częściej wobec matki niż ojca) oraz rodzeństwa.

Spośród ogółu badanych sprawców przemocy domowej wyodrębniono dwie grupy. Pierwszą z nich, tzw. grupę eksperymentalną (ok. 48\%, tj. 133 sprawców) stanowili skazani, którzy byli uczestnikami programów edukacyjno-korekcyjnych dla sprawców przemocy w rodzinie. Zdecydowana większość z nich (103 osoby) po raz pierwszy przystąpiła do programu dopiero w zakładzie karnym, w trakcie odbywanej kary pozbawienia wolności. W tej grupie byli też tacy mężczyźni, którzy ukończyli program w warunkach wolnościowych, przed osadzeniem w zakładzie karnym (30 osób), a niektórzy $\mathrm{z}$ nich dodatkowo poddali się oddziaływaniom o charakterze edukacyjno-korekcyjnym podczas pobytu w placówce penitencjarnej (11 osób). Drugą grupę badanych, tzw. grupę kontrolną, stanowili skazani odbywający karę pozbawienia wolności, którzy nigdy nie uczestniczyli w programach edu- 
kacyjno-korekcyjnych dla sprawców przemocy, zarówno w warunkach środowiska otwartego, jak też w trakcie odbywanej kary pozbawienia wolności (144 osoby, ok. 52\%).

Jak podkreślają wychowawcy penitencjarni, więźniowie skazani za przestępstwo $\mathrm{z}$ art. 207 k.k. niechętnie uczestniczą w programach edukacyjno-korekcyjnych. Dzieje się tak dlatego, że niechętnie przyznają się do stosowania przemocy w rodzinie, stosując różnorodne mechanizmy wypierania. Bardzo często za przemoc obwiniają swoje ofiary, uwypuklając ich wady (np. „Żona była kłótliwa”, „Matka mnie prowokowała, szukała zaczepki” itp.), nierzadko też minimalizują znaczenie krzywdy, jakiej doznawały ich ofiary (np. „To były tylko kłótne, sprzeczki małżeńskie”). Podczas odbywania kary pozbawienia wolności bardzo często demonstrują więc postawę oporu wobec wszelkich podejmowanych względem nich zabiegów resocjalizacyjnych (np. „Nie dam się”, „Nie zrobią mi tutaj prania mózgu”, „Nie zamierzam się zmienić”) i jeśli ostatecznie przystępują do programu edukacyjno-korekcyjnego, to zazwyczaj motywowani dążeniem do osiągnięcia osobistych korzyści, takich jak np. dodatkowe przepustki, widzenia czy warunkowe przedterminowe zwolnienie z odbywanej kary (Głowik, 2013, s. 17; Dybalska, 2012, s. 15; Wojciechowski i Sankowski, 2017, s. 155).

Oczywiście taka postawa skazanego utrudnia efektywność podejmowanych względem niego zabiegów edukacyjno-korekcyjnych, co nie oznacza jednocześnie, iż pod wpływem tychże zabiegów, jego postawa bierności, oporu czy negatywizmu, nie ulegnie zmianie. Bowiem edukacja, jakiej poddawani są sprawcy przemocy domowej, koncentruje się wokół objaśniania mechanizmów powstawania i dynamiki zachowań przemocowych. Sprawca ma możliwość konfrontacji własnych postaw i przekonań na ten temat. Szczególny nacisk kładzie się na uświadomienie mu, jakie zachowania są krzywdzące dla członków rodziny (chodzi tu m.in. o uznanie własnych czynów za akty przemocy), podejmuje się także problem kształtowania odpowiedzialności sprawcy za czyny, których się dopuścił w rodzinie, bez obwiniania ofiar i zaprzeczania ich krzywdzeniu (uznanie własnej i wyłącznej odpowiedzialności za przemoc). Praca ze sprawcą obejmuje ponadto stosowanie procedur behawioralno-poznawczych, pozwalających mu pozyskać określone umiejętności, takich jak np.: umiejętność konstruktywnego wyrażania emocji i pozytyw- 
nej komunikacji interpersonalnej, umiejętność rozwiązywania konfliktów rodzinnych bez użycia przemocy, identyfikowania sygnałów ostrzegawczych zapowiadających zachowania przemocowe czy umiejętność samokontroli. Pozwala to budować sprawcy tzw. plan bezpieczeństwa, zapobiegający bądź przynajmniej minimalizujący ryzyko użycia przemocy wobec członków rodziny. Ogólnie więc, udział sprawcy w programie powinien wiązać się (przynajmniej w założeniu) nie tylko ze zmianą postaw i przekonań na temat przemocy, ale także winien wzbudzać jego motywację do zmiany zachowania oraz kształtować przekonanie, że taka zmiana jest możliwa (por. załącznik 2, cz. IV, pkt 5; Jankowska-Guściora, 2016, s. 120-121; Czerwińska, 2016, s. 166-168; Wójcik, Drapała i Więcek-Durańska, 2015, s. 141-143).

Biorąc pod uwage powyższe, dla potrzeb niniejszej analizy przyjęto założenia mówiące o tym, że skazani, którzy uczestniczyli w programach dla sprawców przemocy domowej, istotnie częściej niż ci, którzy nie brali w nich udziału:

1) przekonani są o skuteczności tego rodzaju oddziaływań w powstrzymywaniu sprawców przed dalszym krzywdzeniem osób bliskich;

2) wyrażają gotowość zmiany swojego zachowania i zaprzestania stosowania przemocy w rodzinie;

3) uznają akty przemocy, których się dopuścili, za krzywdzące wobec członków rodziny;

4) uznają własną i wyłączną odpowiedzialność za przemoc w rodzinie.

\section{ANALIZA I INTERPRETACJA WYNIKÓW BADAŃ}

\section{Przekonania o skuteczności programów edukacyjno-korekcyjnych}

Jeśli chodzi o ogólną ocenę efektywności programów edukacyjno-korekcyjnych w powstrzymywaniu sprawców przed dalszym krzywdzeniem członków rodziny, analiza porównawcza wykazała umiarkowane różnice istotne statystycznie ( $<<0,001, \mathrm{~V}$ Kramera=0,30, Chi-kwadrat=24,43) pomiędzy sprawcami, którzy ukończyli program (grupa eksperymentalna), a tymi, którzy nie poddali się tego rodzaju oddziaływaniom (grupa kontrolna) (zob. tabela 1).

Sprawcy w grupie eksperymentalnej (ok. 51\%) dwukrotnie częściej niż w grupie kontrolnej (ok. 26\%) przekonani byli o skuteczności programów 
edukacyjno-korekcyjnych w powstrzymywaniu zachowań przemocowych w rodzinie. Natomiast na brak efektywności tego rodzaju oddziaływań wskazywał średnio co szósty ankietowany, w tym zarówno badani w grupie eksperymentalnej, jak i w grupie kontrolnej (po ok. 16\% wskazań).

Tabela 1.

Skuteczność programów edukacyjno-korekcyjnych w ocenie badanych

\begin{tabular}{|c|c|c|c|c|c|c|}
\hline \multirow{2}{*}{ Odpowiedzi: } & \multicolumn{2}{c|}{$\begin{array}{c}\text { grupa } \\
\text { eksperymentalna }\end{array}$} & \multicolumn{2}{c|}{$\begin{array}{c}\text { grupa } \\
\text { kontrolna }\end{array}$} & \multicolumn{2}{c|}{ ogółem } \\
\cline { 2 - 7 } & $\mathrm{N}$ & $\%$ & $\mathrm{~N}$ & $\%$ & $\mathrm{~N}$ & $\%$ \\
\hline Skuteczne & 68 & 51,1 & 37 & 25,7 & 105 & 37,9 \\
\hline Nieskuteczne & 21 & 15,8 & 23 & 16,0 & 44 & 15,9 \\
\hline Trudno powiedzieć & 44 & 33,1 & 84 & 58,3 & 128 & 46,2 \\
\hline Razem & 133 & 100,0 & 144 & 100,0 & 277 & 100,0 \\
\hline \multicolumn{3}{|c|}{$\mathrm{p}<0,001, \mathrm{r}$ Kramera $=0,28$, Chi-kwadrat=21,33 (df=2) } \\
\hline
\end{tabular}

Źródło: badania własne.

Ogólnie jednak, najliczniejszy odsetek badanych (niepełna połowa, ok. 46\%) nie potrafił jednoznacznie ocenić efektywności programów edukacyjno-korekcyjnych. Istotnie częściej odpowiedź „trudno powiedzieć” (czy programy te są skuteczne bądź nie w powstrzymywaniu zachowań przemocowych w rodzinie) wskazywali ankietowani w grupie kontrolnej (ok. $58 \%$ ). Jednakże oczywistym jest, że osoby, które nigdy nie brały udziału w tego rodzaju oddziaływaniach, nie potrafią ustosunkować się (zarówno twierdząco, jak i przecząco) do pytania o ich efektywność. Natomiast znamiennym pozostaje fakt, że co trzeci ankietowany w grupie eksperymentalnej (ok. 33\%), mimo iż ukończył program dla sprawców przemocy, również nie potrafił wyrazić opinii na temat ich skuteczności. Może to oznaczać, że ich zaangażowanie w programie było znikome lub też - biorąc pod uwagę fakt, iż większość skazanych realizowało te programy w warunkach izolacji penitencjarnej, nie mieli oni, jak dotychczas, możliwości skonfrontowania efektów pozyskanej w programie wiedzy i umiejętności, w tych skądinąd „sztucznych warunkach” i „bez mierzenia się z rzeczywistością" (Jankowska-Guściora, 2016, s. 121). 


\section{Gotowość zmiany własnego zachowania}

Ankietowanych sprawców zapytano także, jak sądzą, czy w przyszłości, już po opuszczeniu zakładu karnego, uda im się powstrzymywać od stosowania przemocy w rodzinie. Oczywiście odpowiedzi udzielane przez skazanych stanowiły jedynie deklaracje dotyczące ich przyszłych zachowań, które ostatecznie mogą nie zostać zrealizowane. Jednak ich wartość diagnostyczna polega na tym, iż ukazują określone pragnienia dotyczące zmiany własnego zachowania lub ich brak.

Tabela 2.

Deklaracje badanych dotyczące przyszłych zachowań w rodzinie

\begin{tabular}{|c|c|c|c|c|c|c|}
\hline \multirow[t]{2}{*}{ Odpowiedzi } & \multicolumn{2}{|c|}{$\begin{array}{c}\text { grupa } \\
\text { eksperymentalna }\end{array}$} & \multicolumn{2}{|c|}{$\begin{array}{c}\text { grupa } \\
\text { kontrolna }\end{array}$} & \multicolumn{2}{|c|}{ ogółem } \\
\hline & $\mathrm{N}$ & $\%$ & $\mathrm{~N}$ & $\%$ & $\mathrm{~N}$ & $\%$ \\
\hline $\begin{array}{c}\text { Będę starał się nie dopuszczać } \\
\text { przemocy }\end{array}$ & 73 & 54,9 & 72 & 50,0 & 145 & 52,3 \\
\hline $\begin{array}{l}\text { Nie wiem, jak będzie, ale raczej } \\
\text { będę się starał nie stosować } \\
\text { przemocy }\end{array}$ & 20 & 15,0 & 14 & 9,7 & 34 & 12,3 \\
\hline $\begin{array}{l}\text { Wszystko zależy od tego, jak będą } \\
\text { zachowywać się członkowie rodziny }\end{array}$ & 9 & 6,8 & 11 & 7,6 & 20 & 7,2 \\
\hline $\begin{array}{l}\text { Nie zamierzam nic zmieniać, nie } \\
\text { czuję się sprawcą przemocy }\end{array}$ & 26 & 19,5 & 43 & 29,9 & 69 & 24,9 \\
\hline $\begin{array}{l}\text { Trudno powiedzieć (lub brak } \\
\text { odpowiedzi) }\end{array}$ & 5 & 3,8 & 4 & 2,8 & 9 & 3,2 \\
\hline Razem & 133 & 100,0 & 144 & 100,0 & 277 & 100,0 \\
\hline \multicolumn{7}{|c|}{$\mathrm{p}=0,283$} \\
\hline
\end{tabular}

Źródło: badania własne.

Ogólnie, badania dowiodły, że średnio co drugi spośród ogółu ankietowanych sprawców deklarował, iż po opuszczeniu zakładu karnego będzie podejmował starania, aby nie dopuszczać się przemocy wobec członków rodziny (ok. 52\%), co ósmy stwierdził, iż jeszcze nie wie, jakie będą jego zachowania, ale zaznaczał, że raczej będzie powstrzymywał się od stosowania przemocy (ok. 12\%). Natomiast ok. 6\% badanych uzależniało swoje przyszłe zachowania 
od tego, jak będą postępować członkowie ich rodziny, zaś co czwarty sprawca kategorycznie stwierdzał, że nie zamierza zmieniać swojego postępowania, gdyż nie czuje się sprawcą przemocy (ok. 25\%). Nie stwierdzono przy tym istotnych statystycznie różnic pomiędzy badanymi w grupie eksperymentalnej i grupie kontrolnej ( $\mathrm{p}=0,283)$. Skazani, którzy ukończyli programy korekcyjne dla sprawców przemocy nieznacznie częściej tylko (różnica 5 pkt procentowych) deklarowali, że wprawdzie nie wiedzą, jakie będą ich przyszłe zachowania, jednak raczej będą starali się nie stosować przemocy w rodzinie. Natomiast sprawcy, którzy nie poddali się oddziaływaniom edukacyjno-korekcyjnym, częściej deklarowali (różnica ok. 10 pkt procentowych), że nie zamierzają niczego zmieniać w swoim postępowaniu, gdyż nie czują się sprawcami przemocy (zob. tabela 2).

Powyższa analiza dowodzi, że mimo, iż skazani, którzy uczestniczyli w programach edukacyjno-korekcyjnych, istotnie częściej przekonani byli o ich efektywności w powstrzymywaniu sprawców przed krzywdzeniem osób najbliższych, to jednak, jeśli chodzi deklaracje dotyczące własnych zachowań przemocowych w rodzinie, nie różniły się one istotnie od deklaracji składanych przez sprawców, którzy nie zostali poddani takim oddziaływaniom. Te różnice mogą być wynikiem tego, iż przyjęto tu dwie różne perspektywy oceny.

W pytaniu o efektywność programów edukacyjno-korekcyjnych (pytanie o następującej treści: Jak ocenia Pan skuteczność takich programów? Czy osoby, które je ukończyły, nie będa już stosować przemocy $w$ rodzinie?) przyjęto tzw. perspektywę obserwatora zachowań nie tyle własnych, co ogólnie „osób, które ukończyły program".

Natomiast pytanie sondujące gotowość badanych do odrzucenia zachowań przemocowych w rodzinie (Jak Pan sadzi, czy po opuszczeniu zakładu karnego uda się Panu powstrzymywać od stosowania przemocy wobec najbliższych?) bezpośrednio odnosiło się do oceny własnych zachowań (tzw. perspektywa aktora).

Perspektywy te odróżnia rodzaj atrybucji, czyli wnioskowania o przyczynach danego zachowania. Obserwator oceniający zachowania „innych” koncentruje się głównie na wewnętrznych predyspozycjach tych osób, a więc ich postawach, cechach osobowości, posiadanych umiejętnościach itp. (tzw. 
atrybucja wewnętrzna), natomiast aktor, wyjaśniając zachowania własne, bardziej skupia się na czynnikach sytuacyjnych, a więc bardziej skłonny jest uzależniać je od okoliczności zewnętrznych czy chociażby postępowania innych osób w otoczeniu (tzw. atrybucja zewnętrzna) (por. Soszyńska i Francuz, 2007, s. 293).

\section{Uznanie aktów krzywdzenia najbliższych za przemoc}

Badanych sprawców zapytano także, jak oceniają swoje zachowania, za które zostali ukarani i osądzeni jako sprawcy przemocy domowej. I jak dowodzą ich wypowiedzi, tylko niespełna co czwarty spośród ogółu ankietowanych uznawał, iż jego zachowania rzeczywiście były przemocą w rodzinie (ok. $23 \%$ ), podczas gdy ponad $2 / 5$ badanych uważało, iż tylko niektóre ich zachowania stanowiły przemoc wobec najbliższych (ok. 44\%), a 1/4 sprawców twierdziła, iż żadne z ich zachowań (mimo, iż zostali ukarani) nie stanowiło przemocy w rodzinie (ok. 26\%) (zob. tabela 3).

Tabela 3.

Stosunek badanych do własnych zachowań przemocowych w rodzinie

\begin{tabular}{|c|c|c|c|c|c|c|}
\hline \multirow{2}{*}{ Odpowiedzi } & \multicolumn{2}{|c|}{$\begin{array}{c}\text { grupa } \\
\text { eksperymentalna }\end{array}$} & \multicolumn{2}{|c|}{ grupa kontrolna } & \multicolumn{2}{|c|}{ ogółem } \\
\hline & $\mathrm{N}$ & $\%$ & $\mathrm{~N}$ & $\%$ & $\mathrm{~N}$ & $\%$ \\
\hline $\begin{array}{l}\text { Moje zachowania były przemocą } \\
\text { wobec najbliższych }\end{array}$ & 31 & 23,3 & 34 & 23,6 & 65 & 23,5 \\
\hline $\begin{array}{c}\text { Tylko niektóre } \mathrm{z} \text { moich } \\
\text { zachowań były przemocą wobec } \\
\text { najbliższych }\end{array}$ & 69 & 51,9 & 53 & 36,8 & 122 & 44,0 \\
\hline $\begin{array}{l}\text { Żadne z moich zachowań nie było } \\
\text { przemocą wobec najbliższych }\end{array}$ & 26 & 19,5 & 47 & 32,6 & 73 & 26,4 \\
\hline Trudno powiedzieć & 7 & 5,3 & 10 & 6,9 & 17 & 6,1 \\
\hline Razem & 133 & 100,0 & 144 & 100,0 & 277 & 100,0 \\
\hline $\mathrm{p}=0,039, \mathrm{~V} \mathrm{~K}$ & nera $=($ & Chi-k & $\mathrm{cat}=8$ & $f=3)$ & & \\
\hline
\end{tabular}

Źródło: badania własne. 
Analiza statystyczna wykazała słabe różnice istotne statystycznie pomiędzy badanymi z grupy eksperymentalnej a badanymi z grupy kontrolnej w zakresie oceny własnych zachowań przemocowych $(\mathrm{p}=0,039$, V Krame$\mathrm{ra}=0,17$, Chi-kwadrat=8,37). Sprawcy uczestniczący w programach edukacyjno-korekcyjnych istotnie częściej niż pozostali uznawali, iż tylko niektóre z ich zachowań, za które zostali ukarani, można uznać za przemoc w rodzinie (odpowiednio: 52\% i 37\% wskazań), natomiast sprawcy, którzy nie byli uczestnikami programów korekcyjnych istotnie częściej wskazywali, iż żadne $\mathrm{z}$ ich zachowań nie stanowiło przemocy wobec bliskich osób (ok. 33\% wskazań dla tej odpowiedzi w grupie kontrolnej i niespełna $20 \%$ - w grupie eksperymentalnej). Jeśli zaś chodzi o „całkowite” uznanie przemocy, której badani byli sprawcami - brak jakichkolwiek różnic pomiędzy skazanymi uczestniczącymi oraz nieuczestniczącymi w oddziaływaniach edukacyjno-korekcyjnych. Ogólnie więc różnice, jakie ujawniły się pomiędzy badanymi, są następujące: sprawcy z grupy eksperymentalnej częściej skłonni byli uznać, przynajmniej „częściowo” własne zachowania za przemoc, natomiast sprawcy z grupy kontrolnej - częściej negowali własne zachowania jako stanowiące przemoc wobec najbliższych.

\section{Poczucie odpowiedzialności za zachowania przemocowe w rodzinie}

Badacze zjawiska przemocy domowej podkreślają, że sprawcy często starają się znaleźć uzasadnienie dla swoich zachowań i nawet jeśli uznają, że ich zachowania są krzywdzące dla bliskich, stosunkowo rzadko przyjmują za nie odpowiedzialność. Swoistym mechanizmem, często stosowanym przez domowych tyranów, jest redukowanie własnej odpowiedzialności za akty przemocy i przerzucanie jej na ofiarę znęcania się (Widera-Wysoczańska, 2010, s. 129).

W badaniach niniejszych również próbowano ustalić, czy ankietowani skłonni są uznać własną odpowiedzialność za akty krzywdzenia najbliższych czy też winą za zaistniałą przemoc obarczają swoje ofiary. Zapytano ich więc, kto - w ich ocenie - był winny zachowań, za które zostali osądzeni i ukarani jako sprawcy przemocy w rodzinie (uzyskane wyniki obrazuje tabela 4). 
Tabela 4.

Poczucie odpowiedzialności badanych za czyny związane ze stosowaniem przemocy

\begin{tabular}{|c|c|c|c|c|c|c|}
\hline \multirow[t]{2}{*}{ Odpowiedzi } & \multicolumn{2}{|c|}{$\begin{array}{c}\text { grupa } \\
\text { eksperymentalna }\end{array}$} & \multicolumn{2}{|c|}{$\begin{array}{c}\text { grupa } \\
\text { kontrolna }\end{array}$} & \multicolumn{2}{|c|}{ ogółem } \\
\hline & $\mathbf{N}$ & $\%$ & $\mathrm{~N}$ & $\%$ & $\mathrm{~N}$ & $\%$ \\
\hline $\begin{array}{l}\text { Winny zachowań przemocowych } \\
\text { byłem wyłącznie ja }\end{array}$ & 37 & 27,8 & 39 & 27,1 & 76 & 27,4 \\
\hline $\begin{array}{l}\text { Nie tylko ja byłem winny, } \\
\text { ale także osoba (osoby) uznana za } \\
\text { pokrzywdzoną }\end{array}$ & 74 & 55,6 & 61 & 42,4 & 135 & 48,7 \\
\hline $\begin{array}{c}\text { Winna była wyłącznie osoba } \\
\text { (osoby) uznana } \\
\text { za pokrzywdzoną }\end{array}$ & 17 & 12,8 & 25 & 17,4 & 42 & 15,2 \\
\hline Trudno powiedzieć & 5 & 3,8 & 19 & 13,2 & 24 & 8,7 \\
\hline Razem & 133 & 100,0 & 144 & 100,0 & 277 & 100,0 \\
\hline $\mathrm{p}=0$ & Chi- & $\mathrm{rat}=10$ & $(\mathrm{df}=3$ & & & \\
\hline
\end{tabular}

Źródło: badania własne.

Jak dowiodła analiza danych, średnio co drugi respondent uznawał, że współwinną stosowanej przez niego przemocy była osoba pokrzywdzona (ok. 49\%), co siódmy badany winą za przemoc obarczał wyłącznie krzywdzonych członków rodziny (ok. 15\%) i już tylko nieco ponad 1/4 sprawców przyjmowała pełną i wyłącznie własną odpowiedzialność za akty przemocowe w rodzinie (ok. 27\%). Nie stwierdzono przy tym istotnych statystycznie różnic pomiędzy badanymi w grupie eksperymentalnej i kontrolnej $(\mathrm{p}=0,014$, Chi-kwadrat=10,58). Niemal identyczny odsetek badanych w obydwu grupach uznawał własną i wyłączną odpowiedzialność za stosowaną w rodzinie przemoc. Tego rodzaju postawę ujawniało ok. $28 \%$ badanych w grupie eksperymentalnej i porównywalny odsetek badanych w grupie kontrolnej (ok. 27\%). Sprawcy, którzy ukończyli programy edukacyjno-korekcyjne nieco częściej tylko gotowi byli uznać współwinę osób pokrzywdzonych (różnica ok. 13 pkt proc.), natomiast sprawcy, którzy nie brali w nich udziału - nieznacznie częściej przejawiali tendencję do „przerzucania” winy na ofiary przemocy (różnica niespełna 5 pkt proc.) i nieco częściej niż sprawcy w grupie eksperymen- 
talnej nie potrafili wskazać, kogo należy winić za przemoc, której dopuścili się w rodzinie się (różnica ok. 9 pkt proc.).

\section{W KIERUNKU SYNTEZY}

Przeprowadzona w niniejszym artykule analiza dowodzi stosunkowo niskiej efektywności programów edukacyjno-korekcyjnych w zakresie kształtowania postaw i przekonań skazanych sprawców przemocy domowej. Wprawdzie skazani, którzy byli uczestnikami tego rodzaju oddziaływań, istotnie częściej niż skazani, którzy nie brali w nich udziału, przekonani byli, iż ogólnie, tego rodzaju programy są skuteczne w powstrzymywaniu sprawców przed dalszym krzywdzeniem członków rodziny, jednak owego przekonania wydają się nie wiązać z własnym postępowaniem. Nie stwierdzono bowiem żadnych różnic pomiędzy badanymi w grupie eksperymentalnej i kontrolnej, jeśli chodzi o deklaracje odnoszące się do ich przyszłych zachowań w rodzinie. Średnio ok. połowa sprawców deklarowała, iż będzie starała się nie stosować przemocy wobec bliskich i tylko nieznacznie częściej byli to badani, którzy ukończyli programy dla sprawców przemocy niż ci, którzy nigdy nie brali w nich udziału (różnica ok. 5 pkt proc.). Dowodzi to, iż przejawiana przez sprawców gotowość zmiany zachowania nie jest rezultatem odziaływań, jakim zostali poddani w ramach programu, a jedynie może być efektem „oddziaływania” na skazanego samego faktu uwięzienia związanego z odbywaną karą.

Nie stwierdzono ponadto zależności, jeśli chodzi o kształtowanie wśród uczestników programów edukacyjno-korekcyjnych postawy „pełnego” uznania swoich zachowań za krzywdzące członków rodziny (tzw. uznanie przemocy), a także uznania przez nich wyłącznie własnej odpowiedzialności za te zachowania. Tylko średnio co czwarty sprawca, zarówno w grupie eksperymentalnej, jak i kontrolnej, skłonny był uznać wszystkie swoje zachowania (za które został ukarany) za akty przemocy domowej, a niespełna co trzeci badany - własną i „pełną” odpowiedzialność za popełnione czyny. Istotne statystycznie różnice pomiędzy badanymi (zależności słabe) dotyczyły jedynie tego, iż sprawcy, którzy ukończyli programy korekcyjne, częściej skłonni byli uznać tylko niektóre swoje zachowania za akty przemocy w rodzinie, zaś sprawcy nie poddani takim oddziaływaniom, częściej wskazywali, że żadne 
z ich zachowań nie było przemocą wobec bliskich. Przy tym, zarówno badani w grupie eksperymentalnej, jak i w grupie kontrolnej, najczęściej przejawiali tendencję do współobwiniania swoich ofiar za przemoc, której się dopuścili $\mathrm{w}$ rodzinie, a niektórzy $\mathrm{z}$ nich - $\mathrm{w}$ tym średnio co ósmy sprawca $\mathrm{z}$ grupy eksperymentalnej i co szósty z grupy kontrolnej - uznawali za „w pełni” odpowiedzialne za przemoc, swoje ofiary.

Niniejsze badania dowodzą więc, że ogólnie „moc” programów edukacyjno-korekcyjnych w zakresie kształtowania postaw i przekonań sprawców na temat stosowanej przemocy, jest stosunkowo niewielka. Może to być związane $\mathrm{z}$ ich niedostateczną motywacją do uczestnictwa $\mathrm{w}$ tego oddziaływaniach w trakcie odbywanej kary, a zwłaszcza traktowaniem udziału w nich instrumentalnie, jako swoistej „przepustki” do ubiegania się o przedterminowe warunkowe zwolnienie z zakładu karnego. Jednocześnie jednak oznaczałoby to, iż ryzyko stosowania przemocy w rodzinie jest wciąż duże i to nie tylko w przypadku skazanych, którzy nie poddali się tego rodzaju oddziaływaniom, ale również w przypadku tych, którzy ukończyli programy dla sprawców przemocy domowej.

Skoro więc rola programów edukacyjno-korekcyjnych u podstaw zmiany postaw i przekonań skazanych na temat stosowanej przemocy jest znikoma, to czy należałoby całkowicie zrezygnować $\mathrm{z}$ ich realizacji w zakładach karnych? Oczywiście wnioskowanie o tym, że programy dla sprawców przemocy są całkowicie nieskuteczne, jedynie na podstawie zaprezentowanych w niniejszym artykule danych, byłoby daleko posuniętym uproszczeniem. Ostateczna weryfikacja efektywności programów edukacyjno-korekcyjnych, zwłaszcza zaś ich skuteczności w powstrzymywaniu sprawców przed dalszym krzywdzeniem osób najbliższych, będzie możliwa dopiero po opuszczeniu przez nich placówki penitencjarnej (chociażby na podstawie ich późniejszej karalności za przestępstwo z art. 207 k.k.). Nie można jednak wykluczyć, że programy te, zwłaszcza w powiązaniu z odpowiednią motywacją skazanego do zmiany, nie okażą się dla niego „przełomowe” u podstaw dążenia do zmiany zachowania. Jak bowiem wskazywał jeden z badanych mężczyzn: To zależy od konkretnego człowieka, czy chce się zmienić, czy nie. To chyba sprawa indywidualna, czy komuś te programy pomoga (R 274). Jednak, aby rozstrzygnąć kwestię znaczenia „odpowiedniej” motywacji sprawcy do udziału 
w programach edukacyjno-korekcyjnych, należałoby przeprowadzić badania porównawcze w populacji osób, które dobrowolnie przystępują do programów edukacyjno-korekcyjnych w warunkach środowiska otwartego.

\section{Literatura}

Babcock, J.C., Green, C.E., Robie, C. (2004). Does batterer treatment work? A meta-analytic review of domestic violence treatment. „Clinical Psychology Review” nr 23 (8), s. 1023-1053. ISSN 0272-7358.

Barnish, M. (2004). Domestic Violence: A Literature Review, London: HM Inspectorate of Probation. ISSN 1543-4613.

Czerwińska, J. (2016). Jaka moc maja programy oddziaływań korekcyjno-edukacyjnych? Przykład województwa ślaskiego. W: J. Frankowiak, L. Willan-Horla i E. Borys (red.). Środowiskowe konteksty przemocy - ku zrozumieniu i w poszukiwaniu rozwiązań, s. 163-176. Olsztyn: Centrum Badań Społecznych UWM. ISBN 9788363911256.

Dybalska, I. (2012). Więzienie koryguje czy wzmacnia? Sprawcy przemocy w rodzinie $w$ więzieniu. „Niebieska Linia” nr 5 (82), s. 12-15. ISSN 1507-2916.

Głowik, T. (2013). „Rodzina” w zakładzie karnym. Program dla sprawców przemocy w rodzinie w izolacji więziennej. „Niebieska Linia” nr 6 (89), s. 16-18. ISSN $1507-$ 2916.

Jackson, S. Feder, L., et. al. (2003). Batterer intervention programs: where do we go from here?, National Institute of Justice Special Report. US Department of Justice. https://www.ncjrs.gov/pdffiles1/nij/195079.pdf (dostęp: 25.01.2018)

Jankowska-Guściora, M. (2016). Sprawcy przemocy domowej - próba oceny prowadzonych oddzialywań penitencjarnych $z$ perspektywy antydyskryminacyjnej. „Annales Universitatis Paedagogicae Cracoviensis. Studia de Cultura" nr 8 (1), s. 117-125. ISSN 2083-7275.

Komenda Główna Policji, Przemoc $w$ rodzinie, http://statystyka.policja.pl/st/wybrane-statystyki/przemoc-w-rodzinie/50863,Przemoc-w-rodzinie.html (dostęp: 07.08.2018).

Lizińczyk, S. (2012a). Antyprzemocowa rewolucja. Służba Więzienna a sprawcy przemocy, „Niebieska Linia” nr 5 (82), s. 10-12. ISSN 1507-2916.

Lizińczyk, S. (2012b). Sprawcy przemocy w polskim systemie więziennictwa, „Niebieska Linia" nr 2 (79), s. 7-10. ISSN 1507-2916. 
Łuka, M. (2010). Działania podejmowane wobec sprawców przemocy. W: J. Maciaszek (red.). Zjawisko przemocy we wspótczesnym świecie. Wybrane aspekty, Stalowa Wola: Wydział Zamiejscowy Nauk o Społeczeństwie KUL. ISBN 9788361307457.

Ministerstwo Pracy i Polityki Społecznej (2015), Sprawozdanie z realizacji Krajowego Programu Przeciwdziałania Przemocy w Rodzinie na lata 2014-2020 za okres od 1 stycznia do 31 grudnia 2014 r., https://www.mpips.gov.pl/przeciwdzialanie-przemocy-w-rodzinie-nowa/ogolne/ sprawozdania-z-realizacji-krajowego-programuprzeciwdzialania-przemocy-w-rodzinie/sprawozdania-z-realizacji-krajowegoprogramu-przeciwdzialania-przemocy-w-rodzinie-na-lata-2014-2020-zarok-2014-/ (dostęp: 09.04.2018).

Rozporządzenie Ministra Pracy i Polityki Społecznej z dnia 22 lutego 2011 r. w sprawie standardu podstawowych usług świadczonych przez specjalistyczne ośrodki wsparcia dla ofiar przemocy, kwalifikacji osób zatrudnionych w tych ośrodkach, szczegółowych kierunków prowadzonych oddziaływań korekcyjno-edukacyjnych wobec osób stosujących przemoc w rodzinie oraz kwalifikacji osób prowadzących oddziaływania korekcyjno-edukacyjne. Dz.U.2011.50.259.

Saunders, D.G. Hamill, R.M. (2003). Violence against women: Synthesis of research on offender interventions. The research report submitted to the U.S. Department of Justice, https://www.ncjrs.gov/pdffiles1/nij/grants/201222.pdf (dostęp: 25.01.2018).

Silvergleid, C.S. Mankowski, E.S. (2006). How batterer intervention programs work. Participant and facilitator accounts of processes of change. „Journal of Interpersonal Violence" nr 21 (1), s. 139-159.

Soszyńska, E. Francuz, P. (2007). Wpływ aktywizacji wyobraźni na myślenie dywergencyjne oraz na odbiór wrażeń płynacych $z$ ciała. W: P. Francuz (red.), Obrazy w umyśle. Studia nad percepcją i wyobraźnia, s. 291-314. Warszawa: Wydawnictwo Naukowe SCHOLAR. ISBN 9788373832466.

TNS OBOP (2010), Diagnoza zjawiska przemocy $w$ rodzinie $w$ Polsce wobec kobiet $i$ wobec mężczyzn, cz. 1, Warszawa: Raport z badań ogólnopolskich. https://www. mpips.gov.pl/gfx/mpips/userfiles/_public/1-2010_\%20Raport-ogolnopolski_K-M_01-03-11.pdf (dostęp: 07.08.2018).

Ustawa z dnia 29 lipca 2005 r. o przeciwdziałaniu przemocy $\mathrm{w}$ rodzinie. Dz.U.2005.180.1493, tekst jednolity.

Widera-Wysoczańska, A. (2010). Mechanizmy przemocy $w$ rodzinie. Z pokolenia na pokolenie. Warszawa: Difin SA. ISBN 9788376413310. 
Witkowska-Paleń, A. (2017). Programy edukacyjno-korekcyjne wsparciem dla rodzin dotkniętych przemocą. W: B. Szluz, A. Szluz, M. Urbańska (red.), Współczesna rodzina. Aspekty prawno-społeczne, s. 176-190. Rzeszów: Wydawnictwo Uniwersytetu Rzeszowskiego. ISBN 9788379964574.

Wójcik, D. Drapała, K. Więcek-Durańska, A. (2015). Ewaluacja programu Trening Zastępowania Agresji ART oraz programu korekcyjno-edukacyjnego Duluth. Raport z badań empirycznych, Warszawa: Instytut Wymiaru Sprawiedliwości.

Wojciechowski, L. Sankowski, J. (2017). Oddziaływania korekcyjne personelu więziennego wobec skazanych z art. 207 i 209 k.k. W: A. Lewicka-Zelent (red.), Przemoc rodzinna. Aspekty psychologiczne, pedagogiczne i prawne, s. 145-160. Warszawa: Difin SA. ISBN 9788380854789.

Załącznik 2. Krajowy Program Przeciwdziałania Przemocy w Rodzinie na lata 2006-2013: Wytyczne do tworzenia modelowych programów korekcyjno-edukacyjnych dla osób stosujących przemoc $w$ rodzinie, https://www.niebieskalinia.pl/attachments/article/4132/zalacznik2-do-kpppwr.pdf (dostęp: 13.04.2018). 
